\title{
Physical protection of extracellular and intracellular DNA in soil aggregates against simulated natural oxidative processes
}

\author{
Shamina Imran Pathan ${ }^{a}$, Paola Arfaioli ${ }^{a}$, Maria Teresa Ceccherini ${ }^{\text {a }}$, Judith Ascher-Jenull ${ }^{\text {, }}$ \\ Paolo Nannipieri ${ }^{a}$, Giacomo Pietramellara ${ }^{\text {a,* }}$, Luigi Paolo D'Acqui ${ }^{\text {b }}$ \\ ${ }^{a}$ Department of Agrifood Production and Environmental Sciences, University of Florence, Piazzale delle Cascine 28, 50144 Florence, Italy \\ ${ }^{\mathrm{b}}$ Research Institute on Terrestrial Ecosystems (IRET), National Research Council (CNR), Via Madonna del Piano 10, Sesto Fiorentino, 50019 Florence, Italy \\ ${ }^{\mathrm{c}}$ Department of Microbiology, University of Innsbruck, 6020 Innsbruck, Austria
}

\section{A R T I C L E I N F O}

\section{Keywords:}

Intracellular DNA (iDNA)

Extracellular DNA (exDNA)

Soil aggregates

Low Temperature Ashing (LTA)

Infrared photoacoustic spectroscopy (PAS)

\begin{abstract}
A B S T R A C T
The combined action of physical protection and chemical stabilisation is the main factor regulating the persistence of soil organic matter (SOM). In particular, physical protection refers to the compartmentalization of SOM and microbial biomass within aggregates. Thus, we have investigated the role of (macro-, meso- and micro-) soil aggregates in the protection of SOM and extracellular and intracellular DNA (eDNA vs iDNA) from oxidative stress by treating aggregates with Low Temperature Ashing (LTA) for different durations (0, 5, 24 and 48 h). DNA (exDNA vs iDNA) was sequentially extracted from the different aggregate size classes, and qualitatively (agarose gel electrophoresis) and quantitatively (fluorimetry; spectrophotometry) analysed, discriminating between double stranded (ds) and single stranded (ss) DNA. In addition, comparative PCR-DGGE (exDNA vs iDNA) was performed to assess the bacterial, fungal and archaeal communities of the different aggregate size classes. The use of LTA enabled to determine the amount of physically protected DNA in different aggregate sizes, evidencing the potential involvement of both exDNA and iDNA in the formation of the aggregates. Our results also provided insights into the important role of soil aggregates in protecting the genetic information of the autochthonous soil microbiota. The PCoA of bacterial, archaeal and fungal DGGE patterns displayed contrasting results. While fungal and archaeal fingerprinting patterns revealed direct relationships with aggregate sizes and LTA treatment, the bacterial community was not affected by these factors. This suggests a selective action of the size of aggregates on the dominant soil microbial community members. Our findings indicate that aggregates provide a protective habitat for the soil microbial community against environmental stress conditions, such as oxidative stress. Further, the specific protection of the soil microbiota (bacteria vs archaea vs fungi) is directly correlated to the size distribution of the microbial community and the aggregate size classes.
\end{abstract}

\section{Introduction}

Soil aggregates are composite soil structures formed through the combined action of cohesion and fragmentation processes. Within these structures the micro-aggregates, composed of diverse mineral, organic and biotic materials formed during pedogenesis by various physical, chemical and biological processes, provide preferential microhabitats protecting soil organic matter (SOM) from degradation (Six et al., 2004; Totsche et al., 2018) and microorganisms from predation up to several decades (Dini-Andreote and van Elsas, 2019). Protection of SOM occurs preferentially within soil micro-aggregates rather than in macroaggregates (Six et al., 2000). Micro-aggregates, with their physico- chemical heterogeneity of surfaces and three-dimensional structure, provide a large variety of ecological niches that contribute to the vast biological diversity found in soils (Totsche et al., 2018). Differently sized soil aggregates correspond to different habitats and play distinctive roles in the formation of soil structure, oxygen diffusion (Ebrahimi and Or, 2016; Sextone et al., 1985), water flow (De Gryze et al., 2006) adsorption or desorption of nutrients (Linquist et al., 1997; Wang et al., 2001) and protection of soil from runoff erosion (Barthès and RooseEric, 2002). Abundances and characteristics of aggregates have a significant impact on activities, biomass, composition and distribution of microbial communities in soil (Fox et al., 2018; Jiang et al., 2011; Nunan et al., 2003; Six et al., 2004). Vice versa, soil microbial activities can affect

\footnotetext{
* Corresponding author at: Department of Agrifood Production and Environmental Sciences, Piazzale delle Cascine 28, 50144 Florence, Italy.

E-mail address: giacomo.pietramellara@unifi.it (G. Pietramellara).
} 
aggregate formation through several processes such as secretion of byproducts and release of exo-polysaccharides, extracellular DNA (exDNA), etc. (Dini-Andreote and van Elsas, 2019).

The environmental DNA pool is made up of its intracellular (iDNA) and exDNA fractions (Nagler et al., 2018; Pietramellara et al., 2009). The specific characterisation of iDNA provides insights into composition and functions of soil microbial communities (Torsvik et al., 1996). Concerning the possible ecological significance of iDNAss (iDNA single strand), it has been reported that the breakdown of genomic DNAss, induced by endogenous or exogenous stress factors, frequently occurs in microbial cells. In most cases, DNA damage occurs in relatively small areas, which can be easily fixed by cellular repair processes (Mirabelli et al., 1985). However, some stressors such as radiations (Mirabelli et al., 1985), heat (Andrew and Greaves, 1979) and highly oxidative conditions (Cadet and Davies, 2017) can cause wider damage to DNA that cannot be fixed by cell repair processes (Mirabelli et al., 1985), thus, gradually accumulating (Cadet and Davies, 2017) and leading to its death (Andrew and Greaves, 1979). Hence, it is reasonable to assume that iDNAss could provide a robust and readily determinable index of microbial stress when compared with the respective iDNAds (iDNA double strand) form.

On the other hand, exDNA contains extracellular genetic information potentially involved in genetic exchange via bacterial transformation (Nelsen et al., 2007), with evolutionary implications in soil (DiniAndreote and van Elsas, 2019). Furthermore, soil exDNA can be a readily available source of nutrients for microorganisms (Mulcahy et al., 2010) and act as selective plant allelopathic substance (Mazzoleni et al., 2015a,b; Paungfoo-Lonhienne et al., 2010, 2016) or as an aggregate stabilising agent (Büks and Kaupenjohann, 2016; O.Y.A. Costa et al., 2018). The discrimination between ds and ss forms of the exDNA fraction of the total soil DNA pool can provide insights into exDNA degradation in soil (Morrissey et al., 2015; Pathan et al., 2020).

Oxidation under controlled laboratory conditions, simulating natural oxidative processes (Eusterhues et al., 2003), can provide insights not only into the stability of SOM but also into the protection of SOM exerted by different classes of soil aggregates (Eusterhues et al., 2003, 2005; Mikutta et al., 2006). The Low Temperature Ashing (LTA) method, based on the use of cold oxygen plasma, allows the controlled removal of SOM from both the surface and inside of soil aggregates without damaging and altering inorganic constituents and thus, without disturbing the aggregate fabric (D'Acqui et al., 1998, 1999, 2017; Pucci et al., 2008). SOM in the peripheral regions of aggregates is easily accessible to free electrons, excited atoms and molecules of plasma, whose rate of diffusion is mainly controlled by soil porosity (Ebrahimi and Or, 2016; Yan et al., 2018). Based on the assumptions that LTA mimics natural oxidative processes and does not depend on the intrinsic nature of organics, it is plausible to hypothesise that the organic $\mathrm{C}$ which remained inside the aggregates after $48 \mathrm{~h}$ of LTA treatment (not any further removal occurs after this time) represents the physically protected pool (D'Acqui et al., 2017). This organic pool, also containing the residual DNA, is inaccessible to soil microorganisms, poorly accessible to $\mathrm{O}_{2}$ due to limited diffusion, and characterised by long SOM turnover times (Lützow et al., 2006; Six et al., 2004; Stockmann et al., 2013).

To the best of our knowledge, there are no studies about LTA applied to soil-aggregates to assess the physical protection of the various soil DNA fractions (iDNA vs exDNA). This study aimed to evaluate the dynamics of the soil DNA pool through soil aggregates fractionation. In particular, the physical protection of both exDNA and iDNA fractions in aggregates of different size classes by using the LTA method. The starting hypotheses of this research were: i) both exDNA and iDNA are differently distributed in soil aggregates of varying size due to the different protection exerted by aggregates on organic molecules against degradation; ii) micro-aggregates represent a more protective environment for DNA than meso- and macro-aggregates. To verify these hypotheses, we sequentially extracted exDNA and iDNA from different aggregate classes subjected to the LTA treatment for different durations
$(0,5,24,48 \mathrm{~h})$ and quali-quantitatively characterised their double stranded (ds) and single stranded (ss) DNA forms. This approach is capable of discriminating the potentially living microbial community (iDNAds) and to determine its physiological status (iDNAss), thus providing detailed information about its response to highly oxidative conditions, as simulated by the LTA treatment. Further, information on the exDNA at a functional level (potential to act as a genetic source) on the basis of its degradative status is well represented by the exDNAss to exDNAds ratio (Pathan et al., 2020). Principal Coordination Analysis (PCoA) of iDNA and exDNA DGGE fingerprinting patterns was performed to assess the dynamics of the potentially living microorganisms (iDNA) and those releasing exDNA molecules in soil aggregates. This approach is assumed to be capable of evidencing the role of exDNA as a source of potential biases in the correct and reliable characterisation of the soil microbial community (Carini et al., 2017). In addition, infrared photoacoustic spectroscopy (IR-PAS) was performed to characterise SOM removed from the different aggregate size classes (D'Acqui et al., 1999, 2017).

\section{Materials and methods}

\subsection{Soil characteristics and aggregate size separation}

Ten $\mathrm{kg}$ of soil were sampled at $0-10 \mathrm{~cm}$ depth for each of the three independent biological replicates from the Vallombrosa Forest $(50 \mathrm{~km}$ east of Florence, Italy), $43^{\circ} 43^{\prime} 55^{\prime \prime} \mathrm{N} 11^{\circ} 33^{\prime} 28^{\prime \prime} \mathrm{E}$, which covers about 13 $\mathrm{km}^{2}$ of the Apennines Range, from about 600 to $1300 \mathrm{~m}$ above sea level. Silver fir (Abies alba Mill.) and European beech (Fagus sylvatica L.) are the dominant tree species of the area. The soil was classified according to US Soil Taxonomy as fine loamy, mixed, mesic, Humic Dystrudept and characterised by an acid $\mathrm{pH}$ (5.5), loam texture, and about $4,6 \%$ and $0.5 \%$ of total organic C and total $\mathrm{N}$ content, respectively (Agnelli et al., 2004; Certini et al., 2003). Samples were collected under vegetation of beech trees and then carefully transported to the laboratory in boxes, stored on ice, to prevent enzymatic degradation of DNA. Then, soils were sieved $(<2 \mathrm{~mm})$, transferred to a nest of sieves and treated for $3 \mathrm{~min}$ at amplitude 0.7 on a Lab particle vibration sieving machine (LMSM 75/ 200, Laarmann, The Netherlands), to obtain the following range-classes of aggregates: $500-1000 \mu \mathrm{m}, 500-100 \mu \mathrm{m}$ and $<100 \mu \mathrm{m}$, termed in this paper as macro-aggregates, meso-aggregates and micro-aggregates, respectively. These ranges were selected to have in class $500-100 \mu \mathrm{m}$ an average of whole aggregates around $250 \mu \mathrm{m}$ and in the one of $<100$ $\mu \mathrm{m}$ an average of whole aggregates around $50 \mu \mathrm{m}$. Based on conceptual models, the limit between micro- and macro-aggregates is conventionally established at $250 \mu \mathrm{m}$, and the aggregates in the selected range can be further differentiated as large micro-aggregates (here named as mesoaggregates) and small micro-aggregates, respectively (Totsche et al., 2018).

\subsection{Low-Temperature Ashing (LTA)}

The LTA procedure was performed with a self-assembled apparatus as described by D'Acqui et al. (1999). The soil samples were placed in the LTA reactor and evacuated at $45 \mathrm{~Pa}$ under oxygen at $20 \mathrm{~mL} \mathrm{~min}^{-1}$ flow rate. The generation of oxygen plasma was obtained with a radiofrequency of $13.56 \mathrm{MHz}$ using a power input of $100 \mathrm{~W}$ and a reflected power of $5 \mathrm{~W}$. Under these conditions, the temperature was maintained below $80{ }^{\circ} \mathrm{C}$. Aliquots $(1 \mathrm{~g})$ of aggregates of the three different size classes were settled directly in the reactor and exposed to LTA for 5, 24, and $48 \mathrm{~h}(\mathrm{~h})$, respectively. The control samples were not LTA treated (0 h) aggregates. The treatments were stopped at $48 \mathrm{~h}$ because no further $\mathrm{C}$ removal - as checked by elemental analysis at the end of each treatment was observed in the tested aggregates beyond this time (plateau phase). The total OC content of not treated aggregates $(0 \mathrm{~h})$ and LTA treated aggregates was determined by dry combustion with the carbon analyser Carlo Erba NA1500 CHNS. The LTA treatment for each aggregate size 
class was replicated 3 times.

\subsection{Infrared photoacoustic spectroscopy (IR-PAS)}

Infrared photoacoustic spectroscopy (IR-PAS) was used to study the composition of SOM at the surface of untreated and LTA-treated aggregates (D'Acqui et al., 1999, 2017). Photoacoustic infrared spectra were recorded by a Perkin-Elmer Spectrum GX2000 spectrometer (running under Spectrum 5.0 software) equipped with a MTEC 300 detector (MTEC, Ames, IA, USA). Spectra were collected in the range of $4000-550 \mathrm{~cm}^{-1}$ at $8 \mathrm{~cm}^{-1}$ of the resolution, and 512 scans were merged. A charcoal blank spectrum was run as a reference. PAS difference spectra were obtained as the difference between spectra collected before and after LTA treatments, to gain insights into the chemical structure of the SOM removed by LTA. PAS difference spectra were smoothed, baseline corrected and normalised as reported by D'Acqui et al. (1999, 2017).

\subsection{Sequential exDNA and iDNA extraction and comparative PCR- DGGE fingerprinting}

Both exDNA and iDNA were extracted from untreated $(0 \mathrm{~h})$ and LTAtreated $(5,24$ and $48 \mathrm{~h})$ soil aggregates $(500-1000 \mu \mathrm{m}, 500-100 \mu \mathrm{m}$ and $<100 \mu \mathrm{m}$ ) using the sequential extraction method described by Ascher et al. (2009). Briefly, $0.5 \mathrm{~g}$ of soil of each aggregate class was used for the sequential DNA extraction. exDNA was obtained by gentle washings in alkaline sodium phosphate buffer $\left(\mathrm{Na}_{2} \mathrm{HPO}_{4}, \mathrm{pH}\right.$ 8). iDNA was extracted from the residual soil pellets using the FastDNA ${ }^{\circledR}$ Spin Kit for Soil (MP Biomedical, USA), according to the Manufacturer's protocol. Both DNA fractions were purified using the Gene Clean procedure, a component of the extraction kit, so to obtain PCR-compatible DNA. The quantification of DNA by Qubit ${ }^{\circledR} 2.0$ fluorometer (Invitrogen, Eugene, Oregon, USA) yielded the amount of the double stranded form of DNA (DNAds). In contrast, the quantification using the PicoDrop Microliter Spectrophotometer at $260 \mathrm{~nm}$ showed the amount of total DNA, that is the sum of DNAds and the single stranded DNA forms (DNAss). The amounts of iDNAss and exDNAss were calculated by subtraction (Gardner and Gunsh, 2017; Pathan et al., 2020). Throughout the manuscript, the term total DNA refers to the DNA concentration measured by PicoDrop Microliter Spectrophotometer, which includes DNAds and DNAss, independently of the target DNA fraction (exDNA vs iDNA). Further, the term "fraction" refers to exDNA and iDNA, while the term "form" refers to DNAds and DNAss. The molecular weight and fragment length distribution of iDNAds and exDNAds were checked on $0.8 \%$ TAE $1 \times$ agarose gel containing ethidium bromide. The primer sets gc-968f/ 1401r (Nübel et al., 1996), FF3990/FR1gc (Vainio and Hantula, 2000) and ARCH519/gcARCH915 (Coolen et al., 2004) were used to amplify the bacterial 16S rRNA gene, the fungal 18S rRNA gene and the archaeal 16S rRNA gene, respectively. The INGENY PhorU system (Ingeny International BV, Netherland) was used to perform DGGE analyses; gel running and staining conditions were those described by (Ascher et al., 2012). Gels were analysed using the GelDoc system imaging analysis software (Bio-Rad Laboratories, USA).

\subsection{Statistical data analysis}

exDNA and iDNA data were analysed by two-way ANOVA and multiple pairwise comparisons (One-way ANOVA). Two-way ANOVA was performed to evaluate the independent and interaction effect of the LTA treatment and aggregate size classes on the different fractions (exDNA, iDNA) and forms (ss and ds) of the soil DNA pool. One-way ANOVA followed by Tukey's HSD test, analysed the effect of the LTA treatment on each aggregate size class. The Quantity-One ${ }^{\circledR}$ (Bio-Rad Laboratories, USA) software was used to analyse the DGGE banding patterns. The lanes were normalised to contain the same amount of total signal after background subtraction. Finally, the effects of LTA treatment and aggregate size on the composition of both iDNA and exDNA were evaluated by PCoA, considering the presence/absence of DGGE bands. All statistical analyses were performed using the PAST (Paleontological Statistic, version 3.5.X) program (Hammer et al., 2001) and R Statistical Environment (R development Core Team, 2008).

\section{Results}

\subsection{Dynamics of C removal by $L T A$}

The LTA treatment caused a rapid C loss within the first $5 \mathrm{~h}$. The OC removed accounted for more than $40 \%$ of the amount in macro- and meso-aggregates and around $30 \%$ of that in the micro-aggregates (Fig. 1). After $5 \mathrm{~h}$, the removal rate was sensibly reduced, and a substantial steady state was already reached after $24 \mathrm{~h}$. After $48 \mathrm{~h}$, no further OC removal occurred. This residual amount - defined by D'Acqui et al. (2017) as physically protected C was highest in the microaggregates (62\%) and accounted for 53\% in macro- and $46 \%$ in mesoaggregates, respectively.

The PAS difference spectra $(0-48 \mathrm{~h})$ (Fig. S1), showed that the organic material (OM) removed by the LTA treatment from meso- and micro-aggregates was similar in terms of its chemical structure, whereas OM removed from macro-aggregates showed differences, being the bands at 1731, 1552 and $1381 \mathrm{~cm}^{-1}$ more intense than in meso- and micro-aggregates. The main peaks of most spectra were due to asymmetric and symmetric $-\mathrm{CH}_{2^{-}}$stretching $\left(2920-2855 \mathrm{~cm}^{-1}\right), \mathrm{C}=\mathrm{O}$ stretching of $\mathrm{COOH}$ groups ( $1720-1740 \mathrm{~cm}^{-1}$ ), amide I or quinone band (1650 $\mathrm{cm}^{-1}$ ) and amide II bands (1552 $\left.\mathrm{cm}^{-1}\right), \mathrm{CH}_{2^{-}}$bending (1440-1460 $\left.\mathrm{cm}^{-1}\right), \mathrm{C}-\mathrm{O}$ stretching of phenolic C-OH $\left(1270 \mathrm{~cm}^{-1}\right)$, and asymmetrical stretching of $\mathrm{COO}^{-}$groups and amine groups of heterocyclic and aliphatic structures $\left(1380 \mathrm{~cm}^{-1}\right)$.

\subsection{The dynamics of DNA removal and its protection under the LTA treatment}

The LTA removal of both exDNA and iDNA fractions and their respective forms (ds and ss) followed a similar trend as found for the $\mathrm{OC}$ removal (Figs. 1 and 2). After a rapid decrease within the first $5 \mathrm{~h}$ for all DNA forms, except those of macro-aggregates, the decrease rate slowed down $(24 \mathrm{~h})$ and remained constant at $48 \mathrm{~h}$. The removal patterns of all DNA forms of macro-aggregates showed a continual decrease rate until $48 \mathrm{~h}$ (Fig. 2). Two-way ANOVA results showed that LTA treatment (T) and aggregate size classes $(S)$ and their interactions $(T \times S)$ had generally a significant effect on all total exDNA and total iDNA fractions, and

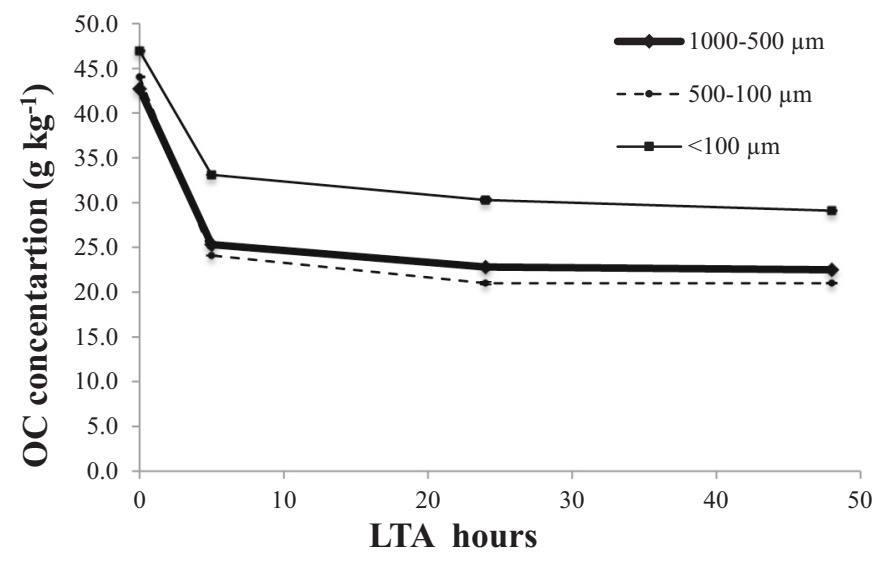

Fig. 1. Dynamics of organic carbon (OC) removal by Low Temperature Ashing (LTA). OC measured in macro-aggregates $(1000-500 \mu \mathrm{m})$, meso-aggregates $(500-100 \mu \mathrm{m})$ and micro-aggregates $(<100 \mu \mathrm{m})$ before $(0 \mathrm{~h})$ and after LTA treatments (5, 24 and $48 \mathrm{~h}$ ). Data represent means and errors of three replicates $(n=3)$. 


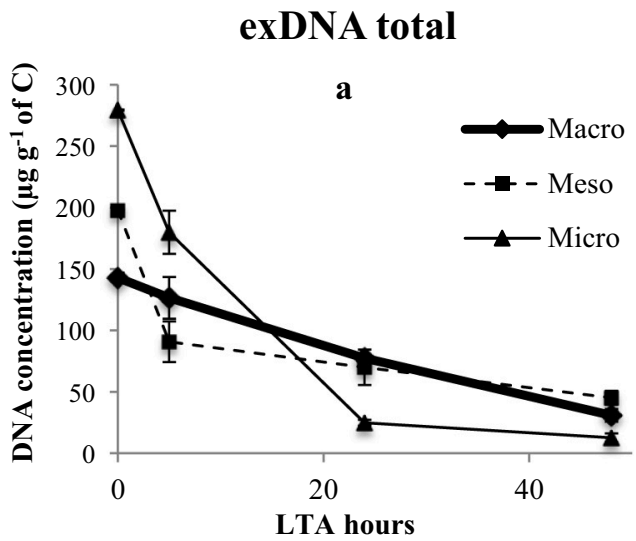

exDNA double strand

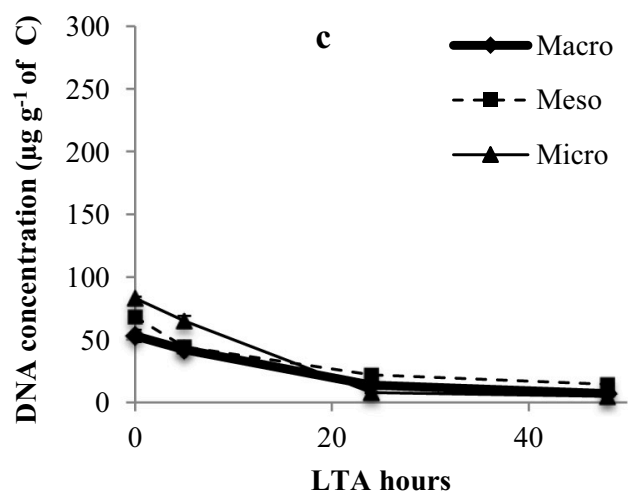

exDNA single strand

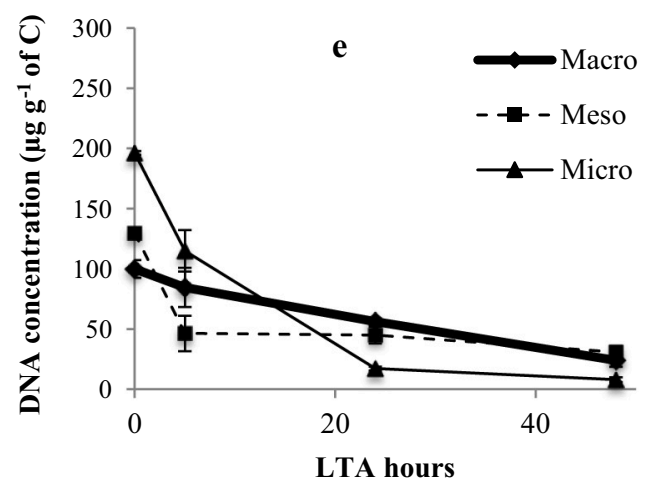

iDNA total

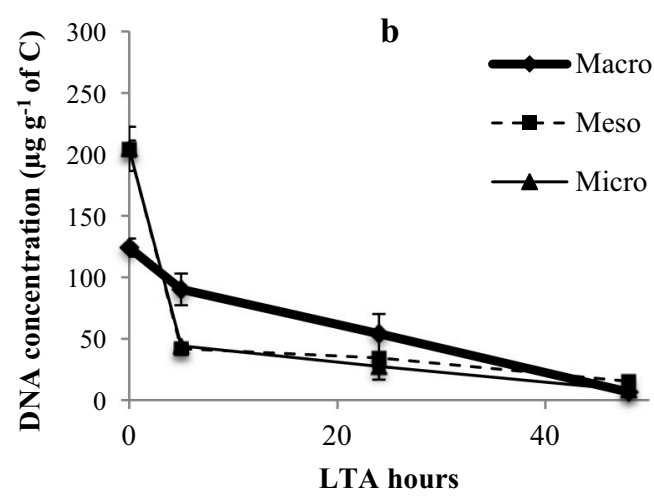

iDNA double strand

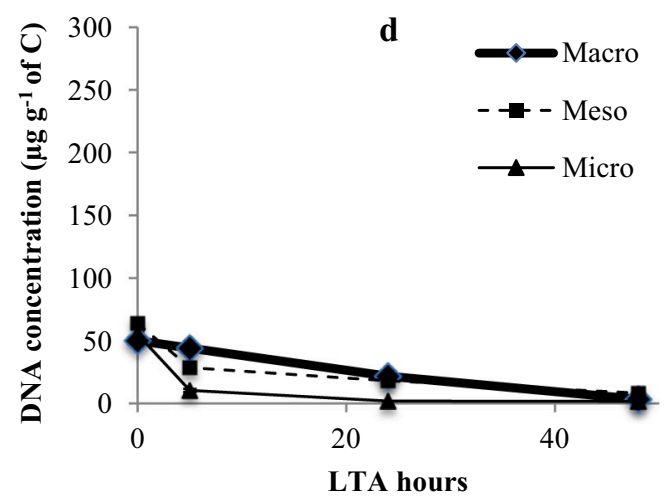

iDNA single strand

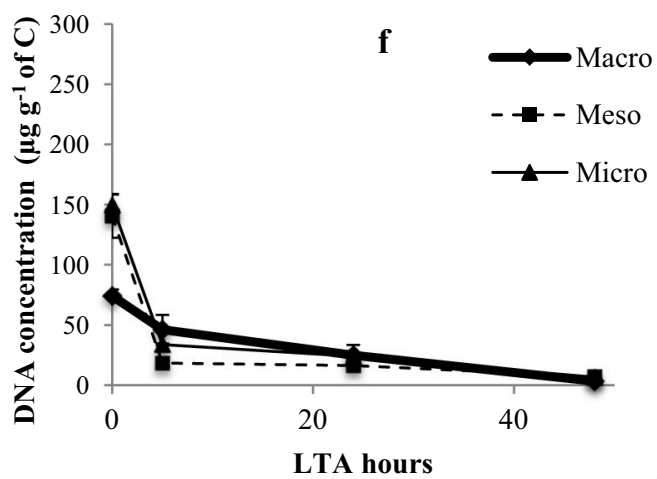

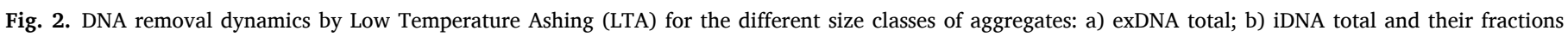

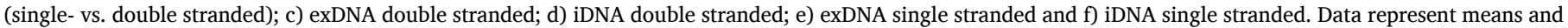
standard errors of three replicates $(n=3)$.

their respective forms (except for the aggregate size effects on total and iDNAss) (Table 1).

The DNA concentrations were calculated on a total OC basis of the different aggregate sizes for the different LTA treatments (Table 2). Among the untreated LTA aggregates ( $0 \mathrm{~h} \mathrm{LTA}$ ) of total DNA (sum of DNAds and DNAss) the micro-aggregates had the significantly highest content of total exDNA and the macro-aggregates had the lowest values for both exDNA and iDNA. In comparison, the meso-aggregates showed similar values for exDNA and iDNA (Fig. 3a). Amounts of DNAss prevailed over the amounts of DNAds in both exDNA and iDNA fractions, accounting for about $2 / 3$ of the respective total DNA (Fig. $3 \mathrm{~b}$ and c). The amount of exDNAss of untreated micro-aggregates was the highest (196.2 $\mu \mathrm{g} \mathrm{g}^{-1}$ of $\mathrm{C}$, accounting for $70.2 \%$ of the respective total DNA). In contrast, double-stranded forms (ds) of both exDNA and iDNA of all of the three aggregate size classes showed the lowest values (Fig. 2b, c and Table 2).

The percentage of physically protected DNA (i.e. the residual $\mathrm{C}$ after $48 \mathrm{~h}$ of LTA treatment), calculated with respect to the amount of the relative untreated aggregates $(0 \mathrm{~h})$, was significantly lower in all DNA forms than the one measured for protected OC (Figs. 1 and $2 a-f$ ). The physically protected percentages of total exDNA were $20.2 \%, 22.8 \%$ and $4.5 \%$ in macro-, meso- and micro-aggregates, respectively (Fig. 4a). 
Table 1

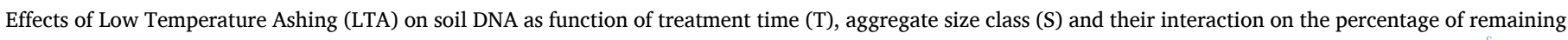

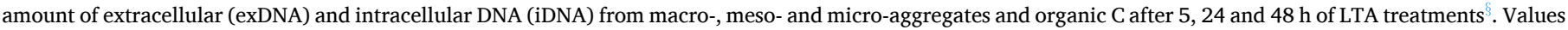
are $F$-values from two-way ANOVA (LTA treatment time $(\mathrm{T}) \times$ aggregate size class (S)).

\begin{tabular}{|c|c|c|c|c|c|c|c|}
\hline \multirow[t]{2}{*}{ Factor } & \multirow[t]{2}{*}{$\mathrm{df}^{\mathrm{a}}$} & \multicolumn{3}{|l|}{ exDNA } & \multicolumn{3}{|l|}{ iDNA } \\
\hline & & Total & dsDNA & ssDNA & Total & dsDNA & ssDNA \\
\hline Aggregate size class (S) & 2 & $5.7^{* * *}$ & $28.2^{* * *}$ & 3.0 & $0.1^{\mathrm{ns}}$ & $34.1 * * *$ & $1.5^{\mathrm{ns}}$ \\
\hline LTA treatment Time $(\mathrm{T})$ & 3 & $134.6^{* * *}$ & $411.3^{* * *}$ & $72.2^{* * *}$ & $115.6^{* * *}$ & $249.9^{* * *}$ & $62.89^{* * *}$ \\
\hline $\mathrm{T} \times \mathrm{S}$ & 6 & $15.2^{* * *}$ & $16.7 * * *$ & $12.0 * * *$ & $7.5^{* * *}$ & $12.48^{*}$ & $5.1 * *$ \\
\hline
\end{tabular}

dsDNA, double stranded DNA; ssDNA, single stranded DNA.

$\S$ Significance: $P<0.1,{ }^{*} P<0.05 ;{ }^{*} P<0.01$; ${ }^{*} *{ }^{*} P<0.001$; ns: not significant.

a Degrees of freedom.

Table 2

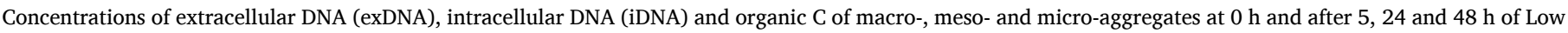

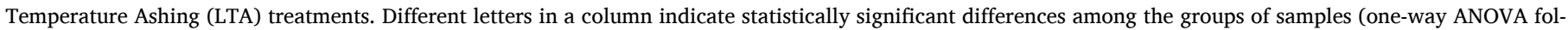
lowed by HSD Tukey's test at $P<0.05$ ).

\begin{tabular}{|c|c|c|c|c|c|c|c|}
\hline \multirow[t]{2}{*}{ Aggregate size classes } & \multirow[t]{2}{*}{ LTA treatment (h) } & \multicolumn{3}{|c|}{ exDNA $\left(\mu g^{-1}\right.$ of $\left.C\right)$} & \multicolumn{3}{|c|}{ iDNA ( $\mu \mathrm{g} \mathrm{g}^{-1}$ of $\left.\mathrm{C}\right)$} \\
\hline & & Total & dsDNA & ssDNA & Total & dsDNA & ssDNA \\
\hline Macro-aggregates & 0 & $142.9 \pm 4.2^{\mathrm{bc}}$ & $53.0 \pm 4.8^{c}$ & $99.8 \pm 7.4^{\mathrm{bc}}$ & $124.1 \pm 7.4^{\mathrm{b}}$ & $50.0 \pm 2.0^{\mathrm{bc}}$ & $74.1 \pm 5.4^{\mathrm{b}}$ \\
\hline \multirow[t]{3}{*}{$1000-500 \mu \mathrm{m}$} & 5 & $126.5 \pm 17.0^{\mathrm{cd}}$ & $42.0 \pm 1.4^{\mathrm{d}}$ & $84.5 \pm 16.2^{\mathrm{bcd}}$ & $90.1 \pm 12.9^{\mathrm{bc}}$ & $44.0 \pm 1.2^{c}$ & $46.1 \pm 12.3^{b c}$ \\
\hline & 24 & $77.5 \pm 2.6^{\text {defg }}$ & $13.9 \pm 0.2^{\mathrm{ef}}$ & $63.7 \pm 2.8^{\text {cde }}$ & $54.0 \pm 16.1^{\mathrm{cd}}$ & $21.7 \pm 1.2^{\mathrm{e}}$ & $24.8 \pm 8.6^{\mathrm{bc}}$ \\
\hline & 48 & $30.9 \pm 5.1^{\mathrm{fgh}}$ & $7.0 \pm 0.3^{f}$ & $23.8 \pm 5.4^{\mathrm{ef}}$ & $6.5 \pm 2.1^{\mathrm{e}}$ & $3.3 \pm 0.1^{\mathrm{gh}}$ & $3.3 \pm 0.6^{\mathrm{c}}$ \\
\hline Meso-aggregates & 0 & $197.8 \pm 0.9^{\mathrm{b}}$ & $68.1 \pm 3.1^{\mathrm{b}}$ & $129.7 \pm 2.1^{\mathrm{b}}$ & $204.4 \pm 18.0^{\mathrm{a}}$ & $63.8 \pm 0.2^{\mathrm{a}}$ & $140.6 \pm 18.2^{\mathrm{a}}$ \\
\hline \multirow[t]{3}{*}{$500-100 \mu \mathrm{m}$} & 5 & $90.7 \pm 16.5^{\mathrm{de}}$ & $44.5 \pm 1.8^{\mathrm{cd}}$ & $46.2 \pm 14.7^{\mathrm{def}}$ & $41.7 \pm 3.1^{\text {cde }}$ & $28.5 \pm 2.3^{\mathrm{d}}$ & $18.4 \pm 1.2^{\mathrm{c}}$ \\
\hline & 24 & $78.7 \pm 14.4^{\mathrm{def}}$ & $22.0 \pm 0.7^{\mathrm{e}}$ & $44.7 \pm 6.9^{\text {cde }}$ & $34.4 \pm 17.8^{\mathrm{de}}$ & $18.0 \pm 1.2^{\mathrm{e}}$ & $16.4 \pm 0.9^{c}$ \\
\hline & 48 & $45.2 \pm 5.7^{\mathrm{efgh}}$ & $14.4 \pm 0.6^{\mathrm{ef}}$ & $30.7 \pm 5.1^{\mathrm{ef}}$ & $15.2 \pm 3.3^{\mathrm{de}}$ & $8.2 \pm 0.1^{\mathrm{fg}}$ & $7.0 \pm 3.2^{\mathrm{c}}$ \\
\hline Micro-aggregates & 0 & $279.3 \pm 0.4^{\mathrm{a}}$ & $83.1 \pm 1.2^{\mathrm{a}}$ & $196.2 \pm 1.5^{\mathrm{a}}$ & $204.5 \pm 6.7^{\mathrm{a}}$ & $55.0 \pm 2.1^{\mathrm{b}}$ & $149.5 \pm 8.8^{\mathrm{a}}$ \\
\hline \multirow[t]{3}{*}{$<100 \mu \mathrm{m}$} & 5 & $179.9 \pm 17.5^{\mathrm{b}}$ & $65.0 \pm 3.9^{\mathrm{b}}$ & $114.8 \pm 17.2^{\mathrm{b}}$ & $44.1 \pm 1.9^{\text {cde }}$ & $10.4 \pm 1.2^{\mathrm{f}}$ & $33.8 \pm 0.8^{\mathrm{bc}}$ \\
\hline & 24 & $24.9 \pm 2.4^{\mathrm{gh}}$ & $7.9 .0 \pm 0.4^{\mathrm{f}}$ & $17.0 \pm 1.6^{\mathrm{ef}}$ & $27.4 \pm 1.7^{\mathrm{de}}$ & $2.0 \pm 0.0^{\mathrm{gh}}$ & $23.8 \pm 1.7^{\mathrm{bc}}$ \\
\hline & 48 & $12.6 \pm 3.6^{\mathrm{h}}$ & $4.8 \pm 0.2^{\mathrm{f}}$ & $7.8 \pm 2.0^{f}$ & $8.2 \pm 1.0^{\mathrm{e}}$ & $1.6 \pm 0.1^{\mathrm{h}}$ & $6.5 \pm 1.7^{c}$ \\
\hline
\end{tabular}

These values showed that total exDNA was less physically protected in micro-aggregates than in the other two aggregate size classes. On the contrary, total iDNA showed comparable percentages of physically protected DNA, being 5.3\%, 7.5\% and $4.0 \%$ for macro, meso- and microaggregates, respectively. Concerning the DNAds forms, both exDNA and iDNA of meso-aggregates were more preserved $(21.2 \%$ and $12.9 \%$, respectively) than those of macro- ( $13.2 \%$ and $6.5 \%$, respectively) and micro-aggregates (9.3\% and $2.9 \%$, respectively) (Fig. 4b). As it concerns the physically protected DNAss forms, those of exDNA of macro(23.9\%) and meso-aggregates $(23.7 \%)$ were more preserved than those in the micro-aggregates (4.0\%) and those of iDNA (4.4\%, 5.0\% and 4.4\% in micro-, meso- and micro-aggregates, respectively) (Fig. 4c). Furthermore, the agarose gel electrophoresis of both DNA fractions showed their rapid degradation during the LTA treatments, as reflected by a marked reduction of the molecular size of the DNA fragments, expressed as base pairs (bp) (Fig. 2). Concerning the size of the DNA fragments, the agarose gels revealed a higher protective action of macroaggregates on both iDNA and exDNA fragments with respect to mesoaggregates and micro-aggregates. The size of DNA fragments in macro- and meso-aggregates after $5 \mathrm{~h}$ and $24 \mathrm{~h}$ of LTA treatment were about $200-100 \mathrm{bp}$ and $>100 \mathrm{bp}$, respectively. Whereas in microaggregates, no fragments resisted to a LTA treatment of $5 \mathrm{~h}$, or, at least, they were degraded to amounts below the detection limit. Further, the iDNAss/iDNAds ratio was calculated and used as a microbial community stress index. Results showed similar trends before and after the LTA treatment with higher values in micro-aggregates with respect to meso- and macro-aggregates in descending order (Table 3).

\subsection{Distribution of microbial exDNA and iDNA before and after different durations of LTA treatment}

Principal Coordinate Analysis (PCoA) based on Bray-Curtis similarity distance of the DGGE patterns of bacterial, fungal and archaeal DNA fractions (both exDNA and iDNA) are shown in Fig. 5. The exDNA-based composition of the bacterial community did not show differences as function of different aggregate size classes and different LTA treatment periods (Fig. 5). On the contrary, the iDNA-based composition of the bacterial community of the LTA-treated micro-aggregates at $48 \mathrm{~h}$ was different from those of meso- and macro-aggregates and to those within the same aggregate fraction after 5 and $24 \mathrm{~h}$ of LTA treatment.

The PCoA plots of the fungal community displayed that the exDNAbased community clustered together irrespective of the LTA treatment period only in macro-aggregates (Fig. 5). Instead, the iDNA-based community clustered together regardless of the LTA treatment period in meso- and macro-aggregates (except the $24 \mathrm{~h}$ meso-aggregate) and the micro-aggregates resulted randomly distributed $(0 \mathrm{~h}$ and $5 \mathrm{~h}$ were clustered together while $24 \mathrm{~h}$ and $48 \mathrm{~h}$ were clustered separately from each other and other times). In addition, fungal iDNA of macro- and meso-aggregates clustered together closely (Fig. 5).

Compared to bacteria and fungi, archaea community showed differences as function of different aggregate size classes and different LTA treatment. The composition of archaea revealed by exDNA-based DGGE of all the three aggregate size classes after $48 \mathrm{~h}$ was similar, as they clustered together (Fig. 5). Further, archaeal exDNA based community were clustered together regardless of the LTA treatment in mesoaggregates except $48 \mathrm{~h}$, while archaeal iDNA of the undisturbed aggregates ( $0 \mathrm{~h}$ LTA, control) clustered together for all three classes of aggregates. Further, iDNA based community in macro- and mesoaggregates were clustered together under 24 and 48 h LTA treatments, while communities in micro-aggregates were clustered together after LTA treatments compared to undistributed aggregates $(0 \mathrm{~h})$.

Moreover, the bacterial DGGE patterns showed that the community profile generated by using exDNA as template was characterised by a higher number of bands compared to those based on iDNA. Interestingly, opposite results were found for fungi and archaea with higher numbers of DGGE bands when iDNA was used as template (Data not shown). 

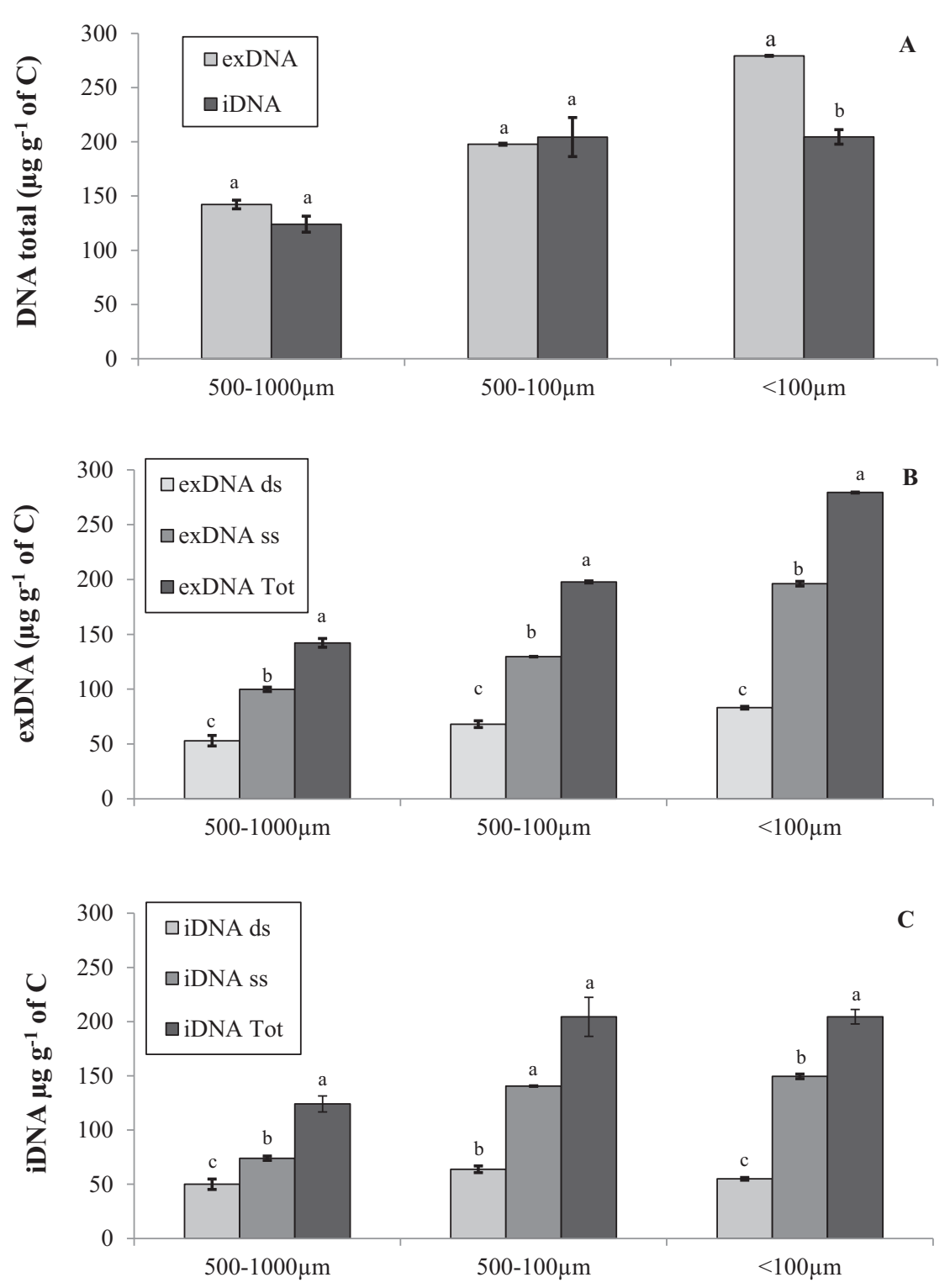

Fig. 3. Amounts of different types (extracellular- vs. intracellular DNA) and forms of soil DNA: a) amount of total exDNA and total iDNA (Total; sum of ds and ss DNA) in undisturbed aggregates (not LTA treated, $0 \mathrm{~h}$ ) of different sizes; b) amount of exDNA and c) iDNA in all of the three forms (total, ds and ss DNA) from undisturbed (not LTA treated) aggregate of different sizes. Data represent means and errors of three replicates. Different letters indicate statistically significant differences between DNA forms (oneway ANOVA followed by Tukey post hoc test, $p<0.05$ ).

\section{Discussion}

We have investigated the effects of natural oxidative processes simulated by the LTA method (D'Acqui et al., 2017) to gain insights into the protection of SOM and DNA fractions (exDNA vs iDNA) and forms (DNAds vs DNAss) exerted by different soil aggregate classes. The LTAinduced $\mathrm{C}$ removal from the aggregates is a function of the characteristics and organisation of soil particles (i.e. soil aggregates structure), which determines the size, shape, and network of pores and, thus, the plasma accessibility. The type of protection we accounted for within the aggregates plausibly entails the inaccessibility of soil microorganisms and limitation of $\mathrm{O}_{2}$ with obvious reduction of bio-chemical activities and turnover time (D'Acqui et al., 2017; Lützow et al., 2006; Six et al., 2004; Stockmann et al., 2013). Both DNAds and DNAss forms were studied to get information about the integrity of bacterial, fungal and archaeal exDNA and iDNA fractions. The exDNA "fragment size" is crucial for maintaining its genetic information in the extracellular soil environment and thus, for the potential bacterial transformation (i.e. horizontal gene transfer) (Pietramellara et al., 2009). However, it is important to bear in mind that the mechanical/physical separation of soil sample into the different aggregate size classes through sieving, even if it is not a harsh treatment for soil microorganisms, may have caused microbial cells lysis, thus overestimating the amounts of exDNA with respect to iDNA.

The degradation rate of all DNA forms (total, ds and ss DNA) of exDNA and iDNA was higher after $5 \mathrm{~h}$ than after $24 \mathrm{~h}$ and $48 \mathrm{~h}$, suggesting that these DNA forms were not stabilised by their interactions with the mineral fraction and as a consequence easily reachable by plasma oxidation. This DNA pattern is similar to the one of OM removal (Figs. 1 and 2), where the rapid reduction of OM after $5 \mathrm{~h}$ of LTA treatment is attributed to the oxidation of particulate organic matter (POM) that is occurring free inside the aggregates and does not chemically interact with the mineral phase within the aggregates (D'Acqui et al., 2017). During the intermediate stages of LTA treatments within 0-48 h, high molecular weight substances were broken down into lower molecular weight substances (for example, DNA molecules were broken down into small DNA fragments, nucleotides, nucleosides and bases) and oxidised rapidly. Therefore, it is reasonable to hypothesise that these temporary fragments produced during plasma treatment and the ones potentially arisen by sieving could have minor effect during the intermediate phases but were not anymore present in the sample collected after $48 \mathrm{~h}$.

The greater amounts of exDNA (total DNA, DNAds and DNAss) of the untreated micro-aggregates than that of meso-and macro-aggregates 

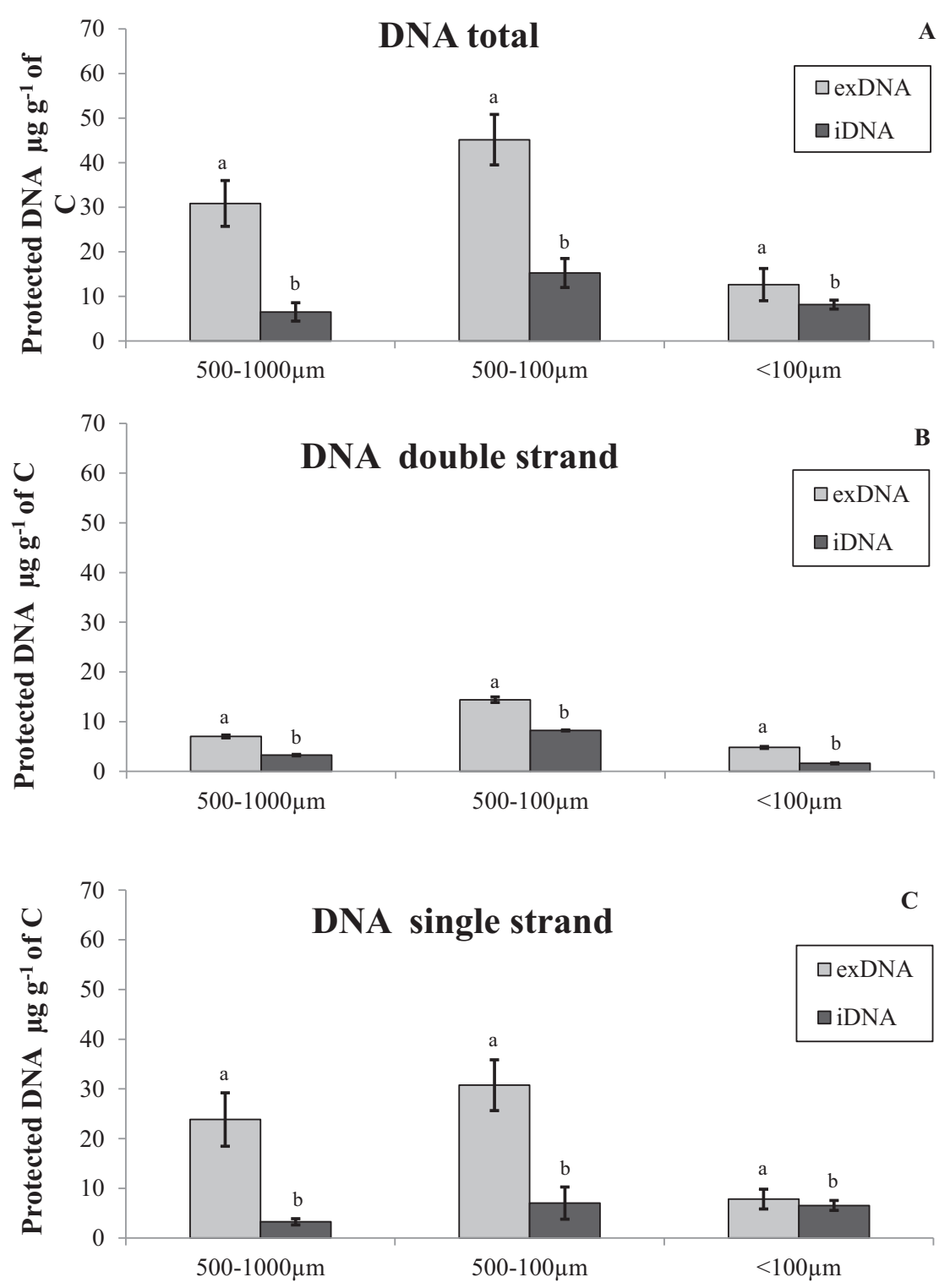

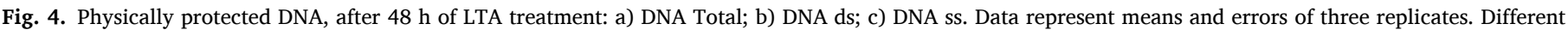
lowercase letters indicate statistically significant differences between DNA forms (One-way ANOVA followed by Tukey post hoc test, $\mathrm{p}<0.05$ ).

Table 3

Microbial community stress index calculated by iDNAss/iDNAds ratio for macro, meso- and micro-aggregates at $0 \mathrm{~h}$ and after 5, 24 and $48 \mathrm{~h}$ of Low Temperature Ashing (LTA) treatments. Different letters in a column indicate statistically significant differences among different LTA time within each aggregate size class (one-way ANOVA followed by HSD Tukey's test at $P<0.05$ ).

\begin{tabular}{lcl}
\hline Aggregate size classes & LTA treatment $(\mathrm{h})$ & Stress index (iDNAss/iDNAds) \\
\hline Macro-aggregates & 0 & $1.48 \pm 0.05^{\mathrm{a}}$ \\
$1000-500 \mu \mathrm{m}$ & 5 & $1.04 \pm 0.27^{\mathrm{a}}$ \\
& 24 & $1.17 \pm 0.47^{\mathrm{a}}$ \\
& 48 & $1.00 \pm 0.20^{\mathrm{a}}$ \\
Meso-aggregates & 0 & $2.20 \pm 0.29^{\mathrm{a}}$ \\
$500-100 \mu \mathrm{m}$ & 5 & $0.65 \pm 0.02^{\mathrm{b}}$ \\
& 24 & $0.30 \pm 0.03^{\mathrm{b}}$ \\
Micro-aggregates & 48 & $0.85 \pm 0.39^{\mathrm{b}}$ \\
$<100 \mu \mathrm{m}$ & 0 & $2.74 \pm 0.27^{\mathrm{b}}$ \\
& 5 & $3.33 \pm 0.37^{\mathrm{b}}$ \\
& 24 & $12.56 \pm 0.65^{\mathrm{a}}$ \\
\hline
\end{tabular}

(Fig. 2b and Table 1) may be attributed to: i) the microbial lysis caused by the soil sieving which was higher in the micro- than in macro- and meso-aggregates; ii) the strong interactions of exDNA with surfacereactive minerals and organic components affecting the architecture of soil aggregate structure which are larger in micro-aggregates than in meso- and macro-aggregates (Pietramellara et al., 2009); and iii) the physical protection of exDNA against microbial degradation due to the smaller size and to possible reduced connectivity of pores in microaggregates than in macro- and meso-aggregates (Rabbi et al., 2016). These conditions may limit microbial accessibility and the diffusion of extracellular nucleases to the physically protected exDNA molecules, as it has been reported for other organic molecules (Keil and Mayer, 2013; Lützow et al., 2006; McCarthy et al., 2008). The preferential accumulation of exDNAss with respect to exDNAds forms in untreated aggregates (Fig. 3b) may be ascribed to the fact that the exDNAss molecules can interact stronger with organo-mineral particles than exDNAds molecules, likely contributing more to the formation of aggregates (Cleaves II et al., 2011). Ladd et al. (1996) reported that soil fine fractions contained higher amounts of extracellular $\mathrm{N}$ organic compounds (released during the microbial metabolism of organic inputs) than the 
Bacteria
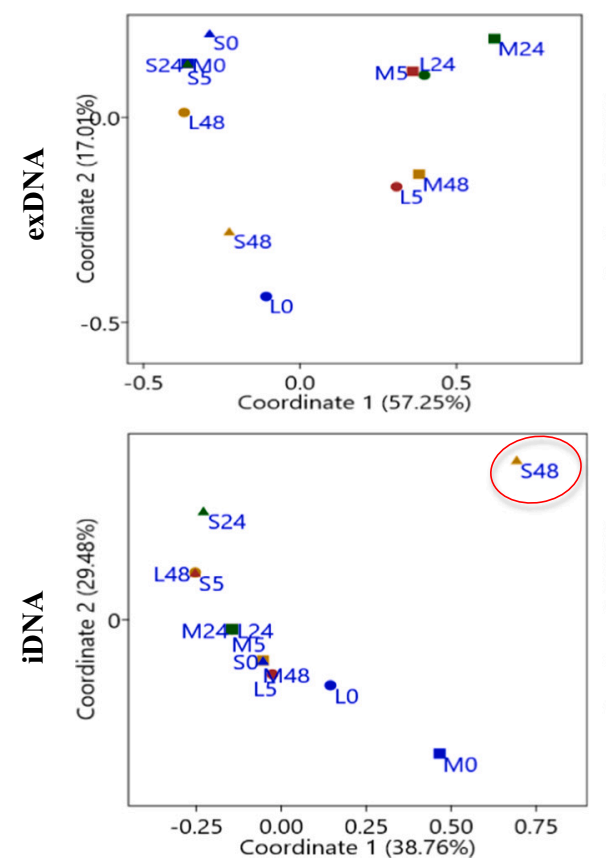

Fungi
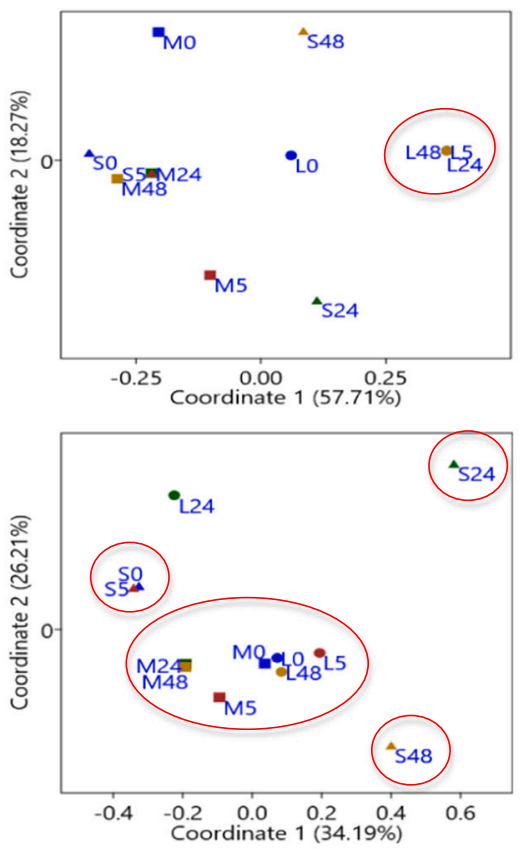

Archaea
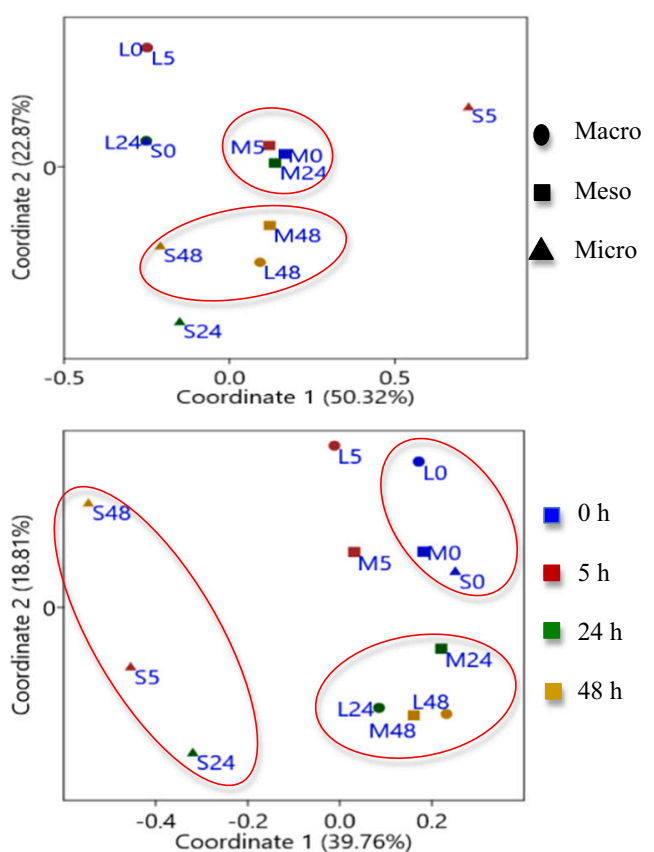

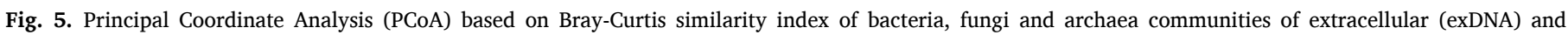

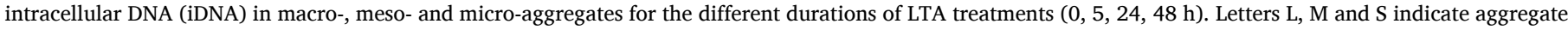
sizes for macro-, meso- and micro-aggregates, respectively.

coarse fractions. Similar processes may occur in micro-aggregates for important biological molecules such as DNA. By contrast, if we take into account the physically protected DNA (i.e. the residual amount of exDNA after $48 \mathrm{~h}$ of LTA treatment), the macro- and meso-aggregates exhibited higher residual values than the micro-aggregates (Fig. 3a, b and c). This last finding, that may seem contradictory, instead, would evidence the involvement of the protected exDNA in hierarchical aggregation processes of the soil matrix (Oades and Waters, 1991). In fact, the larger concentration of protected exDNA in macro- and mesoaggregates might be linked to its contribution to connect microaggregates to form larger aggregates through strong and intimate interactions with the mineral and/or organic matrix interfaces (clay, quartz, feldspar, oxides or hydroxides, humic acids extracellular polysaccharides) (Nielsen et al., 2006), resulting therefore, physically protected. Indeed, the fact that (ss- and ds-) exDNA is more abundant and more protected with respect to iDNA supports its important role in forming soil aggregates. Furthermore, the ss forms rather than the ds forms of exDNA are suggested to be more involved in aggregate structure development as cementing agent, as DNAss can interact more easily with surface-reactive particles than DNAds, as discussed above. Future research should verify this hypothesis also considering that several microbial mechanisms are responsible for the formation of soil structure (Nagler et al., 2018). However, not all physically protected DNA forms are likely involved in the direct binding of soil mineral particles to form aggregates (M.F. Costa et al., 2018; Nagler et al., 2018). Some other mechanisms might also be involved in the aggregate's stabilisation processes (e.g. interactions with other organic material or just for entrapment) (Chaney and Swift, 1984; Kumar et al., 2013; Six et al., 2002).

The infrared photoacoustic spectroscopy (IR- PAS) showed that the chemical structure of organic matter (OM) removed from the macroaggregate differed from that of the OM removed from micro- and meso-aggregates. Particularly, the removed protein-based material (Amide $I$ and Amide II) was larger in macro-aggregates than in the other two size classes of aggregates (Fig. S1), likely due to the presence of larger amounts of non-degraded, or slightly degraded OM (i.e. POM).
The amount of organic carbon (OC), as the total DNA (sum of DNAds and DNAss), was higher in micro-than meso- and macro-aggregates (Figs. 1 and 2), thus confirming the potential of micro-aggregates to stabilise SOM (D'Acqui et al., 2017; Keil and Mayer, 2013; Lützow et al., 2006; McCarthy et al., 2008; Six et al., 2004). However, the relative percentage of physically protected OC (protected OC/total OC) was higher than that of physically protected DNA (protected DNA/total DNA), indicating that most of the OC of soil aggregates was not associated with either exDNA or microbes (iDNA) (Figs. 1 and 2a-f). These results would substantiate the hypothesis that microbial metabolism is a less significant regulator of soil OC decomposition than the microbial habitat properties (i.e. pore network, etc.) (Kemmitt et al., 2008; Ruamps et al., 2013).

The composition of bacterial, fungal and archaeal communities inhabiting the various aggregate size classes was assessed by comparative PCR-DGGE of sequentially extracted exDNA vs iDNA, to gain insights into the origin of the different DNA fractions of aggregates. Although the applied genetic fingerprinting method (DGGE) is restricted to reveal dominant populations of microbial communities, it is yet a fast and reproducible technique which allows an easy comparison and molecular screening of different samples (Muyzer and Smalla, 1998). In fact, although there are well known restrictions of the DGGE method (Nannipieri et al., 2003, 2017), our findings confirm that DGGE is capable to specifically answer well defined research questions, especially when performing comparative DGGE based on the fine-tuning DNA approach: exDNA vs iDNA of the total soil DNA pool (Agnelli et al., 2004; Ascher et al., 2009; Chroňáková et al., 2013). Generally, exDNA was characterised by higher genetic biodiversity, expressed as and reflected by the number of DGGE bands, compared to iDNA. The additional exDNA bands could be ascribed to DNA released from dominant and potentially also from rare species that survived in soil due to physical protection of exDNA molecules by i) adsorption onto surfacereactive soil particles or ii) entrapment in micro-pores, thus preventing their degradation by extracellular nucleases (Ascher et al., 2009; Nagler et al., 2018; Pietramellara et al., 2006, 2009). Further, this aspect also evidences the potential impact of the exDNA fraction on the 
characterisation of the microbial community (Carini et al., 2017). Therefore, for the correct interpretation of microbial community data, also the potential masking effect of exDNA over iDNA of the total DNA pool (environmental DNA) has to be taken into account, especially when molecular screening is performed on directly extracted total environmental DNA, as performed routinely (Corinaldesi et al., 2018; Nagler et al., 2018, 2021; Nannipieri et al., 2020).

The PCoA of bacterial, archaeal and fungal DGGE patterns displayed contrasting results. There were no differences between bacterial DGGE patterns of exDNA and iDNA as function of either aggregate size classes or LTA treatments. Anyways, potential differences might be revealed by employing higher resolution taxonomical investigations based on amplicon sequencing or metagenome approach (Nannipieri et al., 2003, 2017). In contrast, fungal and archaeal DGGE-patterns showed direct relationships with both aggregate size classes and the LTA treatment, which evidenced a selective action of aggregate sizes on the predominant community members (Six et al., 2000, 2004). The fungal community mainly prevailed in macro- and meso-aggregates, especially for iDNA. The higher occurrence of fungi in larger aggregates with respect to smaller ones is expected due to their size distribution (5-50 $\mu \mathrm{m}$ average size), thus requiring larger pores for their establishment than bacteria $(0.5-5 \mu \mathrm{m}$ average size) which can colonise also smaller pores (Wilpiszeski et al., 2019). The physical properties/size ranges of eukaryotic cells such as fungi in the samples soils versus the effect of the analyses of the examined aggregate sizes could perhaps benefit from more attention in further work. Further, the fungal mycelium is known to act as a 'sticky string bag' entangling particles within the hyphal network and cementing particles together through extracellular polysaccharides (EPS) production, thus contributing to the formation of large aggregates (Oades and Waters, 1991; Six et al., 2004; Wilpiszeski et al., 2019).

Interestingly, the dominant archaeal community members displayed different behaviour with respect to bacteria and fungi. In fact, they clustered irrespectively of the aggregate size classes, showing similarities within the LTA treatments. This was particularly evident for the protected exDNA (i.e. $48 \mathrm{~h}$ LTA treatment) and the undisturbed iDNA (0 $\mathrm{h}$ LTA). Probably these differences in microbial community distributions could be ascribed to the physico-chemical characteristics of the different sizes of aggregates that play a vital role in determining the ecology of various microbial communities, their distinct metabolic activities and their survival rates in environmental stress (Six et al., 2004; Wilpiszeski et al., 2019). However, with the present data it is difficult to give further explanations and certainly, as above reported, deeper taxonomical investigations are needed to gain a broader picture of these complex dynamics.

In relation to the level of oxidative stress on the DNA of living cells (iDNAss/iDNAds- stress index), our data evidenced that living cells were less stressed inside of micro-aggregates compared to meso- and macroaggregates (Table 3 ). This phenomenon could be ascribed to the physical characteristics of the micro-aggregates that increase the isolation of its inhabiting microbial community with respect to those colonising the meso- and macro-aggregates. From these data, even if preliminary, the dominance of the physical properties of aggregates in affecting the oxidation dynamics on the microbial community with respect to exogenous factors is shown.

The discussion of our findings is limited due to the lack of similar experiments. In fact, our study is the first attempt of studying the different size classes of soil aggregates as protecting agents of soil OM against natural oxidation simulated by the LTA method. Our focus was on the protection of the autochthonous microbial community based on a fine-tuning DNA approach, i.e. discriminating not only between the extracellular and intracellular fractions of the soil DNA pool but also between the single- and double stranded DNA forms. Our findings provide interesting information that encourages further investigations on the potential of soil aggregates to protect its microbiota within the context of future climate-change scenarios.

\section{Conclusion}

Among all studied aggregate size classes, the highest amount of DNA was found in the micro-aggregates, where exDNA was the prevailing DNA fraction. This indicates the important role of the soil microaggregates in protecting/preserving i) the genetic information in the soil ecosystem and thus, ii) the potential bacterial transformation in terms of horizontal gene transfer, with possible evolutionary implications. Furthermore, the single stranded DNA form generally prevailed over the double stranded form, independently of the DNA fraction (exDNA vs iDNA) and aggregate size class. This finding indicates the predominance of the degraded forms of the DNA pool and a diffuse stress situation in the soil inhabiting microbial community mainly induced by endogenous (aggregate property) and not exogenous factors (LTA treatment). Further, the use of the LTA method to simulate the oxidative degradation combined with the quantitative and qualitative assessment of the physically protected DNA evidenced the potential involvement of exDNAss in the formation of macro- and meso-aggregates.

The different aggregate sizes evidenced the selective action on the dominant microbial community members, showing, through the finetuning DNA analysis, that the fungal community prevailed in macroand meso-aggregates over micro-aggregates. These implications lead to strengthen the emerging view of considering the persistence, other than the soil organic matter, of microbial genetic information related to soil property and functions. However, to better understand the role of microbial communities of soil aggregates with regard to overall OM dynamics, further studies on different soil types and applying higher resolution molecular downstream analyses are needed. Moreover, a potential bias due to different extraction efficiencies needs future investigation.

\section{Declaration of competing interest}

The authors have no affiliation with any organization with a direct or indirect financial interest in the subject matter discussed in the manuscript.

\section{Acknowledgements}

The authors gratefully acknowledge Mr. Dodero Alessandro for his assistance in soil sampling and $\mathrm{C}$ and $\mathrm{N}$ analysis. This research was supported by the Ministry for Education and Research, project "PRIN 2009MWY5F9".

\section{Appendix A. Supplementary data}

Supplementary data to this article can be found online at https://doi. org/10.1016/j.apsoil.2021.104002.

\section{References}

Agnelli, A., Ascher, J., Corti, G., Ceccherini, M.T., Nannipieri, P., Pietramellara, G., 2004. Distribution of microbial communities in a forest soil profile investigated by microbial biomass, soil respiration and DGGE of total and extracellular DNA. Soil Biol. Biochem. https://doi.org/10.1016/j.soilbio.2004.02.004.

Andrew, M.H.E., Greaves, J.P., 1979. Production of single strand breaks in the DNA of Streptococcus faecalis after mild heating. J. Gen. Microbiol. 111, 239-242. https:// doi.org/10.1099/00221287-111-1-239.

Ascher, J., Ceccherini, M.T., Pantani, O.L., Agnelli, A., Borgogni, F., Guerri, G., Nannipieri, P., Pietramellara, G., 2009. Sequential extraction and genetic fingerprinting of a forest soil metagenome. Appl. Soil Ecol. 42, 176-181. https://doi. org/10.1016/j.apsoil.2009.03.005.

Ascher, J., Sartori, G., Graefe, U., Thornton, B., Ceccherini, M.T., Pietramellara, G., Egli, M., 2012. Are humus forms, mesofauna and microflora in subalpine forest soils sensitive to thermal conditions? Biol. Fertil. Soils 48, 709-725. https://doi.org/ 10.1007/s00374-012-0670-9.

Barthès, B., RooseEric, 2002. Aggregate stability as an indicator of soil susceptibility to runoff and erosion; validation at several levels. Catena 47, 133-149. 
Büks, F., Kaupenjohann, M., 2016. Enzymatic biofilm digestion in soil aggregates facilitates the release of particulate organic matter by sonication. Soil 2, 499-509. https://doi.org/10.5194/soil-2-499-2016.

Cadet, J., Davies, K.J.A., 2017. Oxidative DNA damage \& repair: an introduction. Free Radic. Biol. Med. 107, 2-12. https://doi.org/10.1016/j.freeradbiomed.2017.03.030.

Carini, P., Marsden, P.J., Leff, J.W., Morgan, E.E., S.M, S., Fierer, N., 2017. Relic DNA is abundant in soil and obscures estimates of soil microbial diversity. Nat. Microbiol. 2 16242.

Certini, G., Corti, G., Agnelli, A., Sanesi, G., 2003. Carbon dioxide efflux and concentrations in two soils under temperate forests. Biol. Fertil. Soils 37, 39-46. https://doi.org/10.1007/s00374-002-0560-7.

Chaney, K., Swift, R., 1984. The influence of organic matter on aggregate stability in some British soils. Eur. J. Soil Sci. 35, 223-230.

Chroňáková, A., Ascher-Jenull, J., Jirout, J., Ceccherini, M.T., Elhottová, D. Pietramellara, G., Šimek, M., 2013. Cattle impact on composition of archaeal, bacterial, and fungal communities by comparative fingerprinting of total and extracellular DNA. Biol. Fertil. Soils 49, 351-361.

Cleaves II, J., Crapster-Pregont, E., Jonsson, C.M., Christopher, J.L., Savejensky, D.A. Hazen, R.A., 2011. The adsorption of short single-stranded DNA oligomers to mineral surfaces. Chemosphere 83, 1560-1567.

Coolen, M.J., Hopmans, E.C., Rijpstra, I.C., Muyzer, G., Schouten, S., Volkman, J.K., Damsté, J.S.S., 2004. Evolution of the methane cycle in Ace Lake (Antarctica) during the Holocene: response of methanogens and methanotrophs to environmental change. Org. Geochem. 35, 1151-1167.

Corinaldesi, C., Tangherlini, M., Manea, E., Dell'Anno, A., 2018. Extracellular DNA as a genetic recorder of microbial diversity in benthic deep-sea ecosystems. Sci. Rep. 8 , 1-9. https://doi.org/10.1038/s41598-018-20302-7.

Costa, M.F., Pinto da Costa, J., Duarte, A.C., 2018a. Sampling of micro(nano)plastics in environmental compartments: how to define standard procedures? Curr. Opin. Environ. Sci. Heal. 1, 36-40. https://doi.org/10.1016/j.coesh.2017.10.001.

Costa, O.Y.A., Raaijmakers, J.M., Kuramae, E.E., 2018b. Microbial extracellular polymeric substances: ecological function and impact on soil aggregation. Front. Microbiol. 9, 1-14. https://doi.org/10.3389/fmicb.2018.01636.

D’Acqui, L.P., Santi, C., Sparvoli, E., Churchman, J.G., Ristorti, G.G., 1998. Controlled removal of organic matter from undisturbed aggregates by Low-Temperature Ashing for studies on soil structure stability. In: Proceedings of the World Congress of Soil Science.

D’Acqui, L.P., Chuchman, G., Janik, L., Ristori, G., Weissmann, D., 1999. Effect of organic matter removal by low-temperature ashing on dispersion of undisturbed aggregates from a tropical crusting soil. Geoderma 93, 311-324.

D'Acqui, L.P., Bonetti, A., Pini, R., Certini, G., 2017. Physical protection of organic matter in minesoils assessed by low-temperature ashing (LTA). Geoderma 288, 120-129. https://doi.org/10.1016/j.geoderma.2016.11.009.

De Gryze, S., Six, J., Mreckx, R., 2006. Quantifying water-stable soil aggregate turnover and its implication for soil organic matter dynamics in a model study. Eur. J. Soil Sci. 57.

Dini-Andreote, F., van Elsas, J.D., 2019. The soil microbiome - an overview. In: van Elsas, J.D., T, T.J., Rosado, A.S., Nannipieri, P. (Eds.), Morden Soil Microbiology, Third edition, pp. 37-48.

Ebrahimi, A., Or, D., 2016. Microbial community dynamics in soil aggregates shape biogeochemical gas fluxes from soil profiles - upscaling an aggregate biophysical model. Glob. Chang. Biol. 22, 3141-3156. https://doi.org/10.1111/gcb.13345.

Eusterhues, K., Rumpel, C., Kogel-Knabner, M., 2003. Stabilisation of soil organic matter by interactions with minerals as revealed by mineral dissolution and oxidative degradation. Org. Geochem. 34, 1591-1600.

Eusterhues, K., Rumpel, C., Kogel-Knabner, M., 2005. Stabilization of soil organic matter isolated via oxidative degradation. Org. Geochem. 36, 1567-1575.

Fox, A., Ikoyi, I., Torres-Sallan, G., Lanigan, G., Schmalenberger, A., Wakelin, S., Creamer, R., 2018. The influence of aggregate size fraction and horizon position on microbial community composition. Appl. Soil Ecol. 127, 19-29. https://doi.org/ 10.1016/j.apsoil.2018.02.023.

Gardner, C., Gunsh, C., 2017. Adsorption capacity of multiple DNA sources to clay minerals and environmental soil matrices less than previously estimated. Chemosphere 175, 45-51.

Hammer, Ø., David, H., Ryan, P., 2001. PAST: paleontological statistics software packages for education and data analysis. Palaeontol. Electron. 4, 4-9.

Jiang, X., Shi, X., Liu, W., Wright, A., 2011. Kinetics of net nitrification associated with soil aggregates under conventional and no-tillage in a subtropical rice soil. Plant Soil $347,305-312$.

Keil, R., Mayer, L., 2013. Mineral matrices and organic matter. In: Birrer, B. Falkowaski, P., Freeman, K. (Eds.), Treatise on Geochemistry. Elsevier Science Publishers, Amsterdam, p. 632.

Kemmitt, S., Lanyon, C., Waite, I., Wen, Q., Addiscott, T., Bird, N., O’Donnell, A., Brookes, P.C., 2008. Mineralisation of native soil organic matter is not regulated by the size, activity or composition of the soil microbial biomass - a new perspective. Soil Biol. Biochem. 40, 61-73.

Kumar, R., Rawat, K.S., Singh, J., Singh, A., Rai, A., 2013. Soil aggregation dynamics and carbon sequestration. J. Appl. Nat. Sci. 5, 250-267. https://doi.org/10.31018/jans. v5i1.314.

Ladd, J., Foster, R., Nannipieri, P., Oades, J., 1996. Soil structure and biological activity. In: Stotzky, G., Bollag, J. (Eds.), Soil Biochemistry. Marcel Dekker, New York, pp. 23-77.

Linquist, B.A., Singleton, P.W., Yost, R.S., Cassman, K.G., 1997. Aggregate size effects on the sorption and release of phosphorus in an Ultisol. Soil Sci. Soc. Am. J. 61, 160-166. https://doi.org/10.2136/sssaj1997.03615995006100010024x.
Lützow, M.V., Kögel-Knabner, I., Ekschmitt, K., Matzner, E., Guggenberger, G., Marschner, B., Flessa, H., 2006. Stabilization of organic matter in temperate soils: mechanisms and their relevance under different soil conditions - a review. Eur. J. Soil Sci. 57, 426-445. https://doi.org/10.1111/j.1365-2389.2006.00809.x.

Mazzoleni, S., Bonanomi, G., Incerti, G., Chiusano, M.L., Termolino, P., Mingo, A., Senatore, M., Giannino, F., Cartenì, F., Rietkerk, M., Lanzotti, V., 2015a. Inhibitory and toxic effects of extracellular self-DNA in litter: a mechanism for negative plantsoil feedbacks? New Phytol. 205, 1195-1210. https://doi.org/10.1111/nph.13121.

Mazzoleni, S., Cartenì, F., Bonanomi, G., Senatore, M., Termolino, P., Giannino, F., Incerti, G., Rietkerk, M., Lanzotti, V., Chiusano, M.L., 2015b. Inhibitory effects of extracellular self-DNA: a general biological process? New Phytol. 206, 127-132. https://doi.org/10.1111/nph.13306.

McCarthy, J.F., Ilavsky, J., Jastraw, J., Mayer, L., Perfect, E., Zhuang, J., 2008 Protection of organic carbon in soil microaggregates via restructuring of aggregate porosity and filling of pores with accumulating organic matter. Geochim. Cosmochim. Acta 72, 4725-4744.

Mikutta, R., Kleber, M., Torn, M.S., 2006. Stabilisation of soil organic matter: association with minerals or chemical recalcitrance? Biogeochemistry 77, 25-56.

Mirabelli, C.K., Huang, C.H., Fenwick, R.G., Crooke, S.T., 1985. Quantitative measurement of single- and double-strand breakage of DNA in Escherichia coli by the antitumor antibiotics bleomycin and talisomycin. Antimicrob. Agents Chemother. 27, 460-467. https://doi.org/10.1128/AAC.27.4.460.

Morrissey, E.M., McHugh, T.A., Preteska, L., Hayer, M., Dijkstra, P., Hungate, B.A., Schwartz, E., 2015. Dynamics of extracellular DNA decomposition and bacteria community composition in soil. Soil Biol. Biochem. 86, 42-49. https://doi.org/ 10.1016/j.soilbio.2015.03.020.

Mulcahy, H., Charron-Mazenod, L., Lewenza, S., 2010. Pseudomonas aeruginosa produces an extracellular deoxyribonuclease that is required for utilization of DNA as a nutrient source. Environ. Microbiol. 12, 1621-1629. https://doi.org/10.1111/ j.1462-2920.2010.02208.x.

Muyzer, G., Smalla, K., 1998. Application of denaturing gradient gel electrophoresis (DGGE) and temperature gradient gel electrophoresis (TGGE) in microbil ecology. Antonie Van Leeuwenhoek 73, 127-141.

Nagler, M., Insam, H., Pietramellara, G., Ascher-Jenull, J., 2018. Extracellular DNA in natural environments: features, relevance and applications. Appl. Microbiol. Biotechnol. 102 https://doi.org/10.1007/s00253-018-9120-4.

Nagler, M., Podmirseg, S.M., Mayr, M., Ascher-Jenull, J., Insam, H., 2021. The masking effect of extracellular DNA and robustness of intracellular DNA in anaerobic digester NGS studies: a discriminatory study of the total DNA pool. Mol. Ecol. 30, 438-450. https://doi.org/10.1111/mec.15740.

Nannipieri, P., Ascher-Jenull, J., Ceccherini, M.T., Landi, L., Pietramellara, G., 2003. Microbial diversity and soil functions. Eur. J. Soil Sci. 54, 655-670.

Nannipieri, P., Ascher-Jenull, J., Ceccherini, M.T., Giagnoni, L., Pietramellara, G., Renella, G., 2017. Nannipieri, P., Ascher, J., Ceccherini, M.T., Landi, L., Pietramellara, G. \& Renella, G. 2003. Microbial diversity and soil functions. Eur. J. Soil Sci. 54, 655-670.

Nannipieri, P., Ascher-Jenull, J., Ceccherini, M.T., Pietramellara, G., Renella, G., Schloter, M., 2020. Beyond microbial diversity for predicting soil functions: a mini review. Pedosphere 30, 5-17. https://doi.org/10.1016/S1002-0160(19)60824-6.

Nelsen, W., Yegnasubramanian, S., Agoston, A., Bastian, P., Lee, B., Nakayama, M., De Marzo, A., 2007. Abnormal DNA methylation, epigenetics and prostate cancer. Front. Biosci. 12, 4254-4266.

Nielsen, K., Calamai, L., Pietramellara, G., 2006. Stabilization of extracellular DNA and proteins by transient binding to various soil components. In: Nannipieri, P. Smalla, K. (Eds.), Nucleic Acids and Protiens in Soil. Springer, Berling, Heidelberg, pp. 141-157. https://doi.org/10.1007/3-540-29449-X_7.

Nübel, U., Engelen, B., Felsre, A., Snaidr, J., Wieshuber, A., Amann, R.I., Ludwig, W., Backhaus, H., 1996. Sequence heterogeneities of genes encoding 16S rRNAs in Paenibacillus polymyxa detected by temperature gradient gel electrophoresis. J. Bacteriol. 178, 5636-5643. https://doi.org/10.1128/jb.178.19.5636-5643.1996.

Nunan, N., Wu, K., Young, I.M., Crawford, J.W., Ritz, K., 2003. Spatial distribution of bacterial communities and their relationships with the micro-architecture of soil. FEMS Microbiol. Ecol. 44, 203-215. https://doi.org/10.1016/S0168-6496(03) 00027-8.

Oades, J., Waters, J., 1991. Aggregate hierarchy in soils. J. Agric. Chem. Environ. 29, 815-828.

Pathan, S.I., Arfaioli, P., Ceccherini, M.T., Ascher-Jenull, J., Pietramellara, G., 2020. Preliminary evidences of the presence of extracellular DNA single stranded forms in soil. PLoS One 15, 1-10. https://doi.org/10.1371/journal.pone.0227296.

Paungfoo-Lonhienne, C., Lonhienne, T.G.A., Schmidt, S., 2010. DNA uptake by Arabidopsis induces changes in the expression of CLE peptides which control root morphology. Plant Signal. Behav. 5, 1112-1114. https://doi.org/10.4161/ psb.5.9.12477.

Paungfoo-Lonhienne, C., Lonhienne, T.G.A., Yeoh, Y.K., Donose, B.C., Webb, R.I., Parsons, J., Liao, W., Sagulenko, E., Lakshmanan, P., Hugenholtz, P., Schmidt, S., Ragan, M.A., 2016. Crosstalk between sugarcane and a plant-growth promoting Burkholderia species. Sci. Rep. 6, 1-14. https://doi.org/10.1038/srep37389.

Pietramellara, G., Ceccherini, M.T., Ascher-Jenull, J., Nannipieri, P., 2006. Persistence of transgenic and not transgenic extracellular DNA in soil and bacterial transformation. Riv. Biol. 99, 37-68.

Pietramellara, G., Ascher, J., Borgogni, F., Ceccherini, M.T., Guerri, G., Nannipieri, P., 2009. Extracellular DNA in soil and sediment: fate and ecological relevance. Biol. Fertil. Soils 45, 219-235. https://doi.org/10.1007/s00374-008-0345-8.

Pucci, A., D'Acqui, L.P., Calamai, L., 2008. Fate of prions in soil: interactions of RecPrP with organic matter of soil aggregates as revealed by LTA-PAS. Environ. Sci. Technol. 42, 728-733. https://doi.org/10.1021/es071314q. 
R Development Core Team, 2008. R: A language and environment for statistical computing. R Foundation for Statistical Computing, Vienna. http://www.R-project. org.

Rabbi, S.M.F., Daniel, H., Lockwood, P.V., Macdonald, C., Pereg, L., Tighe, M., Wilson, B. R., Young, I.M., 2016. Physical soil architectural traits are functionally linked to carbon decomposition and bacterial diversity. Sci. Rep. 6, 1-9. https://doi.org/ 10.1038/srep33012.

Ruamps, L.S., Nunan, N., Pouteau, V., Leloup, J., Raynaud, X., Roy, V., Chenu, C., 2013. Regulation of soil organic C mineralisation at the pore scale. FEMS Microbiol. Ecol. 86, 26-35. https://doi.org/10.1111/1574-6941.12078.

Sextone, A., Revsbech, N., Parkin, T., Tiedje, J., 1985. Direct measurement of oxygen profiles and denitrification rates in soil aggregates. Soil Sci. Soc. Am. J. 49, 645-651.

Six, J., Elliott, E.T., Paustian, K., 2000. Soil macroaggregate turnover and microaggregate formation: a mechanism for $\mathrm{C}$ sequestration under no-tillage agriculture. Soil Biol. Biochem. 32, 2099-2103. https://doi.org/10.1016/S0038-0717(00)00179-6.

Six, J., Conant, R., Paul, E., Paustian, K., 2002. Stabilization mechanisms of soil organic matter: implications for C-saturation of soils. Plant Soil 241, 155-176.

Six, J., Bossuyt, H., Degryze, S., Denef, K., 2004. A history of research on the link between (micro)aggregates, soil biota, and soil organic matter dynamics. Soil Tillage Res. 79, 7-31. https://doi.org/10.1016/j.still.2004.03.008.

Stockmann, U., Adams, M.A., Crawford, J.W., Field, D.J., Henakaarchchi, N., Jenkins, M., Minasny, B., McBratney, A.B., Courcelles, V. de R. de, Singh, K., Wheeler, I., Abbott, L., Angers, D.A., Baldock, J., Bird, M., Brookes, P.C., Chenu, C., Jastrow, J.D., Lal, R., Lehmann, J., O’Donnell, A.G., Parton, W.J., Whitehead, D., Zimmermann, M., 2013. The knowns, known unknowns and unknowns of sequestration of soil organic carbon. Agric. Ecosyst. Environ. 164, 80-99. https:// doi.org/10.1016/j.agee.2012.10.001.

Torsvik, V., Sørheim, R., Goksøyr, J., 1996. Total bacterial diversity in soil and sediment communities - a review. J. Ind. Microbiol. Biotechnol. 17, 170-178. https://doi.org/ $10.1007 / \mathrm{bf01574690.}$

Totsche, K.U., Amelung, W., Gerzabek, M.H., Guggenberger, G., Klumpp, E., Knief, C., Lehndorff, E., Mikutta, R., Peth, S., Prechtel, A., Ray, N., Kögel-Knabner, I., 2018. Microaggregates in soils. J. Plant Nutr. Soil Sci. 181, 104-136. https://doi.org/ 10.1002/jpln.201600451.

Vainio, E.J., Hantula, J., 2000. Direct analysis of wood-inhabiting fungi using denaturing gradient gel electrophoresis of amplified ribosomal DNA. Mycol. Res. 104, 927-936. https://doi.org/10.1017/S0953756200002471.

Wang, X., Yost, R.S., Linquist, B.A., 2001. Soil aggregate size affects phosphorus desorption from highly weathered soils and plant growth. Soil Sci. Soc. Am. J. 65, 139-146. https://doi.org/10.2136/sssaj2001.651139x.

Wilpiszeski, R.L., Aufrecht, J.A., Retterer, S.T., Sullivan, M.B., Graham, D.E., Pierce, E. M., Zablocki, O.D., Palumbo, A.V., Elias, D.A., 2019. Soil aggregate microbial communities: towards understanding microbiome interactions at biologically relevant scales. Appl. Environ. Microbiol. 85, 1-18. https://doi.org/10.1128/ AEM.00324-19.

Yan, Z., Bond-Lamberty, B., Todd-Brown, K.E., Bailey, V.L., Li, S., Liu, Congqiang, Liu, Chongxuan, 2018. A moisture function of soil heterotrophic respiration that incorporates microscale processes. Nat. Commun. 9, 1-10. https://doi.org/10.1038/ s41467-018-04971-6. 